ISSN:2528-9527

E-ISSN : 2528-9535

YIl Year: 8

Cilt Volume: 8

Sayı Issue : 14

\title{
Tahir Çağatay'ın Eğitim ve Öğretime Dair Görüşleri
}

\author{
DOI: $10.26466 /$ opus.405531
}

\author{
$\underline{\text { A. Selcen Arslangilay* }}$ \\ *Dr, Gazi Üniversitesi, Gazi Eğitim Fakültesi, Eğitim Bilimleri Bölümü, Eğitim Programları ve \\ Öğretim Anabilim Dalı, Ankara / Türkiye \\ E-Posta: aslihanselcen@yahoo.com ORCID: 0000-0002-6262-9037
}

Öz

Aslen Türkistan Türklerinden olan Prof. Dr. Tahir Çağatay, ülkemizde sosyoloji alanına önemli katkılar sunmuş çok yönlü bir sosyologdur. Türkistan'da başlayıp Türkiye'de son bulan hayat yolculuğunda farklı ülkelerde eğitim gören Çă̆atay, toplumsal olayların açıklanmasında toplumsal yapı, tabakalar ve kurumlar arasındaki bağlantıya vurgu yapmış ve güncel sorunların anlaşılmasına önemli katkılar să̆lamıştır. Bu doğrultuda eğitim ve öğretim konuları üzerine de görüşlerini açıklamış, yaşam şartlarında ve dünyada yaşanan tüm değişimlerin izlenebilmesi için eğitim ve öğretimde yenilik ve reformların yapılmasını toplumsal hayat açısından bir gereklilik olarak belirtmiştir. İlköğretimden yetişkin eğitimine kadar pek çok eğitim türü ve kademesine değinen Çağatay, eğitim ve öğretim hakkındaki görüşlerinde günümüzde de geçerli olan konulara değinmiş ve halen geçerliği olan öneriler sunmuştur.

Anahtar Kelimeler: Tahir Çağatay, eğitim-öğretim, sosyoloji, eğitim sosyolojisi.

OPUS (c) Uluslararası Toplum Araştırmaları Dergisi-International Journal of Society Researches ISSN:2528-9527 E-ISSN : 2528-9535

http://opusjournal.net 
ISSN:2528-9527

E-ISSN : 2528-9535

YIl Year: 8

Cilt Volume: 8

Sayı Issue : 14

Uluslararası Toplum Araştırmaları Dergisi International Journal of Society Researches

Nisan April 2018

Makalenin Gelis Tarihi Received Date: 14/03/2018

Makalenin Kabul Tarihi Accepted Date: 07/04/2018

\title{
Views of Tahir Çağatay on Education and Training
}

\begin{abstract}
Being from Turkistan Turks, Prof. Tahir Çağatay has contributed to the sociology field in our country considerably. In his lifetime starting from Turkistan ending in Turkey, Çağatay has been educated in different countries and has contributed to the understanding of the current problems and focused on the link among social structure, social stratum and institutions in explaining the social events. In this respect, he also stated his views on education and stated that it is necessary to make some innovations in education in order to adjust to the requirements of the age. He also stated that reforms should be made in education. It should be taken into account that Çağatay who has explained his views on education and training through primary to adult education has made suggestions, which are still valid for today.
\end{abstract}

Keywords: Tahir Çağatay, education and training, sociology, sociology of education

OPUS ( $)$ Uluslararası Toplum Araştırmaları Dergisi-International Journal of Society Researches ISSN:2528-9527 E-ISSN : 2528-9535

http://opusjournal.net 


\section{Giriş}

Aslen Türkistan Türklerinden olan Tahir Çağatay (o zamanki soyadıyla 1939 yılında Türkiye'ye gelene kadar: Şakir-Şakirzade) 27 Mart 1902 tarihinde eski bir bilim merkezi olan Taşkent'te doğar. Babası Şakir Bey 1917 Rus İnkılabına kadar Türkistan'ın hatırı sayılır tüccarlarındandır. Tahir Çağatay'ın babası devrimden sonra Afganistan'a iltica eder, senelerce kaçak yaşar, defalarca hapse atılır ve tüm servetini komünist kuvvetlere vermek mecburiyetinde kalır (Yaman, 1999; Torun, 2002; Ayan, 1996, 2008).

Tahir Çağatay ilköğrenimini, doğduğu Taşkent'te, Mescit Yanı Mektebi'nde gördükten sonra, Münevver Kari'nin kurduğu Usul-u Cedit mektebine devam eder. Daha sonra bütün derslerin Rusça okutulduğu ve Türkçenin de ayrı bir dil olarak okutulduğu, Türkistanlılar için açılmış iki dilli Rus Mektebinde okur. Bu sıralarda İstanbul'a gitmek isteyen Çağatay, Rusların Rusça eğitim görülen Gymnasium'una da gitmek ister ancak aile çevresi buna karşı çıkar. Bunun üzerine İdil-Ural'ın Ufa şehrindeki Aliye Medresesi'nde birkaç arkadaşı ile eğitim görmeye başlar ancak iklim çok sert ve hayat şartları da zor olduğu için 1917 yılında arkadaşları Dr. Abdülvahab Oktay ve Sabir Türkistanlı ile birlikte Azerbaycan Muallim Mektebinde ortaokul öğretmenliği okumak için Bakü'ye gider. Yazın Taşkent'e dönerek Türkistan Milli Birliği (TMB)'nin en faal üyelerinden biri olur. 1921 yılına kadar Azerbaycan'da kalan Çağatay, orada da Azeri Milli Hareketine katılır ve oradaki milliyetçi toplulukla işbirliği yapar. Taşkent'e döndükten sonra planladığı yükseköğrenimi için para biriktirip 1922 yılında Feyzullah Hoca hükümeti tarafından Berlin'e gönderilen 70 öğrenci arasına kendi masraflarını karşılayacak şekilde katılır. Çağatay özellikle Werner Sombard Berlin'de olduğu için oraya gitmek ister. Sağlığ1 Berlin'de başladığı eğitimine elvermediği için Güney Almanya'da Heidelberg Ruprecht Karls Üniversitesine kaydolur. 1930 y1lına kadar burada felsefe, sosyoloji ve ekonomi dersleri alır ve doktora tezini "Göçebe Hayat Ekonomisinin Ana Hatları" üzerine tamamlar. Teziyle Türkistan ekonomisinde göçebe hayatın önemli rolünü vurgulayan Çağatay, aynı zamanda ülkesini tanıtarak milli bir hizmet yapmış da olur. Tezi Almanca olarak da yayımlanır (Ayas, 1994; Yaman, 1999; Torun, 2002; Ayan, 2008; 
Ono, 2013; Erbaş, 2015). Almanya'da tezini inceleyen Profesör Alfred Weber Çağatay'ı "bu yazdığın eserle bizim memlekette hakiki anlamıyla ilk etnolojik sosyolojiyi yaptın" diyerek tebrik eder (Ayas, 1994).

1931'de Berlin'e yerleşen Çağatay, Kazan Türklerinden ünlü gazeteci, yazar ve politika adamı Muhammed Ayaz İzhaki'nin Berlin'de Türkoloji eğitimi almış kızı Saadet İshaki ile evlenir (Çağatay, 1984). Berlin'de yakın arkadaşı Dr. Abdülvahab Oktay ve Mustafa Çoyakoğlu ile Türkistan İstiklal Mücadelesi'nin yayın organı olan Yaş Türkistan dergisini kurar ve yönetir (Yaman, 1999). Dergide yer alan makalelerin ortak noktası kültürel varlık ve milli benliği korumaktır ve özellikle Çağatay tarafından yazılan makalelerde kültür emperyalizmine direniş göze çarpmaktadır (Açık, 2009).

Öğrencilere burs verildiği için Berlin'de Yüksek Siyaset Mektebine (Hochschule for Politik) yazılan Çağatay, hem aldığı bursun yarısını dergiye verir hem de kendisini alanında çok iyi olan hocaların yanında geliştirir (Ayas, 1994; Yaman, 1999; Torun, 2002; Ayan, 2008; Ono, 2013). Almanya'da kaldığı süre boyunca Münih'teki “Sovyet Rusya'yı Öğrenme Enstitüsü'nün toplantılarına da katılan Çağatay, bu sayede Sovyetler Birliğinde yapılan tüm yayınları tarama imkânı elde eder ve Sovyetler Birliğini ekonomik açıdan incelediği eserlerde bu enstitü imkânlarından yararlanır. Avrupa ve özellikle Almanya'nın Anti Sovyet hareketleri destekliyor olması Çağatay gibi Sovyet dünyasından Avrupa'ya geçen pek çok bilim adamının buralarda çalışmalar yapmalarını sağlar (Torun, 2002). Türkistan davasını Avrupa'da siyasi olayların kaynaştığı Berlin, Londra, Paris, Varşova ve Cenevre gibi pek çok merkezde bir başına yürüten Çağatay, diğer yazar kadrosuyla birlikte Türkistan bağımsızlık mücadelesini Avrupa basınına taşıma başarısında bulunur (Bayraktar, 2013). Çağatay, Türkiye'ye geldikten sonra da benzeri toplantılara katılmak için yine pek çok kez Almanya'ya gider (Torun, 2002).

2. Dünya Savaşı nedeniyle 1929-1939 yılları arasında yayımlanan derginin kapanması ile büyük üzüntü yaşayan Çağatay, eşi ile birlikte 1939 yılında Ankara'ya gelir. Aslında Çağatay o sıralarda Amerika'dan gelen bir teklif yerine Türkiye'yi tercih etmiştir. Yabancılar yerine kendi hemşerilerine hizmet etmeyi yeğleyen Çağatay ve eşi, kitaplarını Türkiye'ye getirebilmek için bütün ev eşyalarını Berlin'de satarlar (Ayas, 1994; Torun, 
2002). Çağatay Ankara'ya geldikten sonra bir süre Ziraat Bakanlığı müşavirliğinde çalışır, 1948 yılında DTCF Sosyoloji Kürsüsüne girerek hocalığa başlar. 1954'te "Kapitalist İçtimai Nizam ve Bugünkü Durumu" adlı teziyle Doçent, 1963 yılında "Günün Sosyolojisine Giriş" adlı Profesörlük takdim tezi ile profesör olan (Ayas, 1994; Erbaş, 2015) ve 1972 yılında yaş haddinden emekliliğe ayrılan Çağatay, görevine aralıksız 23 yıl devam etmiş tek öğretim üyesidir (Torun, 2002). Çağatay, 1984 yılında Bursa' da vefat eder (Yaman, 1999).

\section{İlmî Yönü ve Türk Sosyolojisindeki Yeri}

Türkiye'ye geldikten sonra 1972 yılına kadar DTCF'de Sosyoloji Bölümünü idare etmiş olan Çağatay, bu fakültede gerçek sosyoloji ilminin kurucusu olarak anılmaktadır (Yaman, 1999). Çağatay'ın yaşam öyküsü aslında onun sosyolojik görüşüne de büyük etki yapmıştır. Türkistanlı bir genç olarak Afganistan, Azerbaycan, Almanya ve Türkiye'de geçen yaşamı düşüncelerini oluşturmaktadır. Özellikle babasının bizzat yaşadıkları nedeniyle Tahir Çağatay Rusları ve komünizmi sevmez; hayatı boyunca ideolojisinde Anti-Rus ve Anti-Sovyet bir tutum sergiler, "Kızıl Emperyalizm" olarak gördüğü sosyalizmi yeren, kapitalizmi öven çalışmalar yapar. Max Weber çizgisini takip eden hocaların öğrencisi olan Çağatay, Alman idealist felsefesinden etkilenir ve sosyal ve doğa bilimlerinin farklı yöntemlerinin olduğunu belirterek bilimler arası yöntem ayrılığına vurgu yapar (Ayan, 2008; Erbaş, 2015).

Çağatay, Sosyoloji Bölümündeki akademik hayatına Ord. Prof. Hans Freyer'in "Sosyoloji Nazariyeleri" isimli eserini tercüme ederek başlar. Ankara Üniversitesi'nde Sosyolojiye Giriş, Sistematik ve Ekonomik Sosyoloji Nazariyeleri gibi sosyolojik dersler ve seminerler verir (Torun, 2002). Göçmen kimliği ile dikkati çeken Çağatay, Ankara Üniversitesinde Prof. Dr. Nihat Nirun, Prof. Dr. Birsen Gökçe ve Doç. Dr. Şevki Güler'e akademik danışmanlık yapar. Kendisi, yaşı ve konuşulan Türkçeye yeteri derecede hakim olmaması nedeniyle bizzat ampirik araştırmalar yapmasa da danışmanlığını yaptığı bahsi geçen hocaları alanda uygulamalı çalışmalar yapmaya teşvik eder (Kasapoğlu, 1999). Yine Çelebi'ye (2008) göre bu açıdan Tahir Çağatay da, hocası Hans Freyer de uygulamalı çalışmalar yapmamış olsalar da, önceden geliştirilen kavram ve kuramları basitçe ele 
almaz ancak yetkinlikle yorumlayarak aktarırlar. Türk sosyoloji dünyası Hannah Arendt'i Tahir Çağatay'dan öğrenir.

Türk sosyolojisine en önemli katkı sağlayan eseri "Günün Sosyolojisine Giriş" adlı kitabıdır. Bu kitap, sistematik anlamda modern sosyolojiye bir giriştir ve modern sosyolojiyi bilimsel açıdan ele almıştır (Ayas, 1994). Yine bu kitapta sosyolojinin görevini "her şeyden önce, çok ince bir şekilde nüanslaşmış bir sosyal teşekküller öğretisi yaratmaktadır" şeklinde açıklar (Kasapoğlu, 1999). Öğrencisi Prof. Dr. Nihat Nirun'a göre Çağatay'ın sosyolojisinde sosyal mobilite, bireysel mobilite ve rekabet önemli yer tutar. Kendisi bizzat pek çok ülke arasında (Taşkent, Moskova, Almanya ve Türkiye) hareket ettiği için bireyin hareketliliği üzerinde çokça durur. Ayrıca kadın konusunu ilk ele alan sosyologdur. Aile ve evli çiftler üzerine makaleler yazmıştır. Sosyal bütünden hareket etmeyi seven Çağatay (Kasapoğlu, 1999), sosyal hareketliliğin anlaşılabilmesi için sosyal olayların açıklanmasını sağlayan toplumsal yapı ve toplumsal tabakaların anlaşılması gerektiğini belirtir (Çeçen, 1977).

Çağatay, topluma yön veren teknik gelişmelerden biri saydığı basınyayın faaliyetlerinin yani medyanın gücüne işaret eder ve bu konuda sosyologlara uygulama alanı gösterir (Torun, 2002). Bu açıdan Erdoğan (2009), Çağatay dişında diğer sosyologların iletişim konusunu özel alan olarak ele almadıklarını belirtir. Kitle iletişim ve medyanın yanında sinema ve edebiyat konuları üzerine de çalışan Çağatay, Ayan'ın (2008) da belirttiği gibi hem geleneksel sosyoloji hem de dönemi açısından yenilik sayılan şeyleri ele almıştır.

Çağatay'ın kitapları yayımlandıktan sonra Türkiye'deki sosyoloji çalışmalarında önemli birer kaynak olarak ele alınmış ve pek çok ciddi sosyoloji çalışmasında mutlaka kendisinden yararlanılmıştır. Bunu sağlayan da Çağatay'ın eserlerinde sosyolojinin konusu, yöntemi ve terminolojisini açık bir şekilde ifade etmesidir (Sarıtaş, 1985). Her ne kadar ideolojisini önemli derecede etkilemiş olsa da, bilim hayatında tarafsızlığa büyük önem verdiği için, üniversitede hiçbir zaman özellikle Sovyetler Birliği hakkındaki fikri eserlerini bulundurmaz. Hatta "Yaş Türkistan" dergisindeki yazılarında da takma isimler kullanır (Torun, 2002). Hayat ve eğitim hikâyesinden de görüleceği gibi Çağatay kendini çok yönlü yetiştirmiş bir sosyologdur. Anadili olan Türkçenin yanı sıra Rusça ve Almancaya hâki- 
miyeti ile bu dillerdeki çalışmaları da inceleme şansını elde etmiştir. Çağatay, sosyoloji, felsefe, hukuk, iktisat, tarih, sosyal ekonomi ve zirai ekonomi gibi alanlarda kendisini yetiştirmiş olan çok yönlü bir bilim adamıdir (Torun, 2002).

\section{Eğitim ve Öğretime Dair Görüşleri}

Prof. Dr. Tahir Çağatay, doğrudan eğitim ve öğretim hakkındaki düşüncelerinin yer aldığı makalelerini Türk Yurdu Dergisinin 1959 yılında çıkan sayılarında "Öğretim ve Eğitimde Yenilik Içtimâ̂ Zarurettir" adıyla üç seri olarak yayımlamıştır. Bu makaleler aynı zamanda Çağatay'ın "Günün Sosyolojisine Giriş" adlı kitabında da yer almaktadır.

Eğitim hem etkileyen hem de etkilenen önemli bir sosyal olgudur (Güçlü, 2015). Çağatay, eğitim ve öğretim konusunun en eski ve ilkel zamanlardan dahi bile insan zihnini meşgul eden toplumsal sorunlardan biri olarak açıklar. Çağatay, Sovyet rejimine eğitim öğretim konusunda da vurgu yapar ve eğitimi Sovyet rejimi teknokratlarının beslendiği ve insanın doğasına önem vermeden yeni insan yaratmak için kullandıkları ana kaynak olarak nitelendirir. Her toplumda eğitimin, kişinin o topluma uygun şekilde yetiştirilmesi olarak ele alındığını belirtir (Çağatay, 1959).

Eğitimin toplumsal fonksiyonu üzerine vurgu yapan Çağatay, bu aç1dan eğitimin gençleri içinde doğup yaşadıkları topluma olumlu ve faydalı olabilmeleri amacını güttügünü, kişiler açısından ise herkesin kendi elinde bulunan yeteneklerini geliştirerek olumlu kişilikler elde etme amacı olarak tanımlar. Eğitim ve öğretimi her zaman toplumsal bir konu olarak ele alan Çağatay, bu açıdan içinde yaşanılan topluluğun zaman ve mekân şartına bağlı olduğunu vurgular (Çağatay, 1959). Üç serilik makalesinin adı da, "yeniliğin şart olmasını" vurgulaması açısından dikkate değerdir.

Toplumda şimdiye kadar görülmemiş çok hızlı değişmeler yaşandığ1 için insan zihni bunları takip etmede sorunlar yaşar ve dolayısıyla kültürel gelişim açısından verimsizlik ve durgunluk gibi olaylar ortaya çıkar. Çağatay'a göre bu sorunları "eğitim konularıla ilgilenen bir bilgi disiplini" olarak tanımladığı "pedagoji" tek başına çözemeyecektir. Dolayısıyla eğitim sosyolojisi ve felsefesi gibi disiplinler mecburen ortaya çıkacaktır. Eğer bu kadar hızla gelişen ve değişen toplumlarda eğitim toplumsal bir 
sorun olarak ele alınmazsa, yani sosyoloji eğitimle gerektiği kadar iç içe olmazsa sorunlar çözülemeyecektir. Eğitimi ele alırken tarih bakımından inceleme yapılması da unutulmamalıdır. 2. Dünya Savaşını etkileri ve diğer toplumsal değişimler toplumların sınıf yapısını da önemli ölçüde değiştirmiştir; tüm bunlar da eğitimi ve ne yönde yapılacağını etkilemektedir (Çağatay, 1959).

Yaşanan toplumsal değişmeler, aile yapısının da eğitim açısından eskisi kadar kuvvetli olmamasına ve bu kurumun çocuğu eğitme ve terbiye etme konusunda zayıflamasına neden olmaktadır. Hâlbuki önceleri aile çocuğun dinî, ahlaki, toplumsal ve zihinsel olarak eğitimini tek başına dahi sağlamaktadır. Şimdi etkisini bu derecede kaybeden ailenin yerine geçen resmi ya da gayri resmi kurumlar da gerekli görevi yerine getiremeyeceklerdir. Çağatay'a göre artık, örf, adet ve geleneklerin eskisi kadar değerli olmaması, hayatın her alanında niteliğin yerine niceliğin geçiyor olması, bürokrasi, ekonomi, parti gibi toplumsal varlıklar arasındaki çekişmeler kültür gelişmesine olumsuz etkilerde bulunmaktadır. Dolay-sıyla böyle bir dönemde bütün toplumların eğitimlerini yeniden gözden geçirmeleri ve toplumların kişilere vereceği görevlere göre yeniden ele almaları gerekmektedir. Çünkü okullar artık eskisi gibi durağan olmayan bu dinamik toplumlara ayak uyduramamaktadır. Artık gündeme ayak uyduramayan okullar tek bilgi edindirme yerleri değildir. Basın, kitap, radyo yayınları, film, sinema, çeşitli dernekler, yaşlıların öğretim ve eğitimi, iş yerleri öğretimi gibi bilgi edinme yol ve vasıtaları türemiştir. Bunlar öğretimin yanında eğitim konusunda da aile ve okulların sessiz ortakları olmuşlardır (Çağatay, 1959).

Okul diplomaları da eski etkisini kaybetmiştir, artık iktisadi ve idari kuruluşlar sınavla eleman almakta, mesleki kurslarda ya da tezgâh başında yetiştirme yoluyla da işe girmeler olmaktadır. Dolayısıyla hem okulların hem de okullarda verilen eğitimde kullanılan öğretim yöntem ve tekniklerinin de acilen çağın gereklerine uygun bir şekilde yenilenmesi şarttır. Yenileme yapılırken her toplumun kendi özellikleri dikkate alınmalıdır. Aksi takdirde sadece taklitçilik olumsuz sonuçlar doğuracaktır (Çağatay, 1959). 
Toplumların değişen özellikleriyle birlikte eğitim ve öğretimde de yenilikler yapılmasını savunduğu makaleler serisinin ikincisinde eğitimi, tarihsel gelişimi açısından ele alan Çağatay, ataerkil aile düzeninin etkin olduğu dönemlerde gençlerin eğitim ihtiyacını karşılayan tek otoritenin aile olduğunu ancak ataerkil düzenin etkisini kaybetmesiyle ailenin eğitim görevine başka ortaklar çıktığını belirtir. Ancak Çağatay'a göre çocuk ve gencin olumlu ve doğru bir yönde gelişmesi aile ve bu yeni ortakların arasındaki işbirliği ve işbölümünün başarısına bağlıdır. Ne kadar iyi olsalar da okullar suni ortamlar oldukları ve çocuğun gününün 5-6 saatini geçirdikleri yerler olduğundan, çocukların daha fazla zaman geçirdikleri çevrelerinin okulların amaçladıklarını destekler nitelikte olması gerekir. Dolayısıyla aile ve aile çevresi okulun çocuğa kazandırmak istediklerini çocuğa sunabilecek kültürel bir seviyeye ulaşmalıdır (Çağatay, 1959a).

Eğitim kurumlarında sosyal olgu ve olayların, sosyal gerçekliğin yorumlanması ve öğretimi özellikle okulla çevre arasında bağ kurulması açısından önem taşımaktadır (Güçlü, 2013). Bu nedenle eğitim kurumlarında istenen başarının sağlanmasında okul ve çevre arasında işbirliği gerekmektedir. Fakat Çağatay'a göre (1959a) okul ve aile çevresi arasındaki işbirliği sağlansa dahi yine yeterli değildir çünkü çocuklar bu iki kurumun da dışında dış dünyanın etkisi altında kalabilmekte ve olumsuz etkilenebilmektedir. İşte bu açıdan aile yine öyle bir kültür seviyesinde olmalıdır ki çocuğunun dış dünyadan olumsuz etkilenme tehlikesini hissetmeli ve bu durumu engellemelidir. İşte bu noktada da anne ve babanın bu açıdan yükseltilmesi, yani eğitimi kendini gösterir. Batılı ülkelerde yaşanılan çocuk ve genç suçluluk olaylarına da değinen Çağatay (1959a), özellikle Amerika'nın Rock'n Roll müziğini önlem olarak kullanmasını, bu müzik türündeki şarkıların sözleri ile çocuk ve gençleri etkileyip bu tarz olaylardan korumaya çalışmalarına dikkat çeker.

Eğitim ve öğretime dair yazılarında da kapitalist düzene vurgu yapan Çağatay, sömürgecilik yapan ve sömürge olan ülkeler arasındaki farka dikkat çekmiştir. Sömürgecilik yapan ülkeler, sömürdükleri ülkeler sayesinde elde ettikleri kültür ve refah seviyesini korumak isterken, sömürge konumundaki ülkeler de bir kalkınma hamlesi ile bu durumlarından kurtulup modern kültür ve yaşam seviyesine ulaşma isteğindelerdir. Hollanda gibi kendisinden çok daha büyük ülkeleri sömürge etmiş bir ülke- 
nin 2. Dünya savaşı sonrasında bu sömürgeleri kaybetmesi ile hayat standartlarını artık tek başlarına sürdüremeyeceklerini fark etmeleri ile akıllı eğitim politikaları uygulayarak eksikliklerini giderdiklerini önemli bir örnek olarak sunar. Yazılarında eğitim ve öğretimde yeniliklerin sürekli olmasını savunan Çağatay, sömürgeleri sayesindeki avantajlı durumunu kaybeden bu ülkenin yeni şartlara uyum sağlamak için eğitim ve öğretim sisteminde yaptığ reformları takdir eder. Hollanda, ilköğretim seviyesinden başladığ 1 reformlar ile diğer kademeleri de geliştirir ve hiçbir yetenek ya da enerjinin boşa gitmemesi için çalışır. Dolayısıyla değişen toplumsal koşullara yapılan reformlarla ayak uydurmuş olurlar. Çağatay, sömürge olmaktan yavaş yavaş kurtulan Çin, Hindistan ve diğer Asya ve Afrika ülkelerine de vurgu yapar, bu ülkelerin hayat ve kültürlerini düzenlemek için çaba içinde olduklarını belirtir (Çağatay, 1959a).

Tüm dünyada artık hem toplumsal hem de ekonomik faaliyetlerin rasyonel bir hale geldiğini belirten Çağatay, bu yüzden her bireyin yapacağ 1 görevi en iyi şekilde yerine getirecek kültürel seviyeye ulaşmış olması gerektiğini söyler. Yaşanan gelişmelere tarımsal faaliyetlerden bir örnek sunan Çağatay, eskiden sadece öküz ve saban süren bir kişinin artık gelişen teknolojiye ayak uydurmasının gerekliliğini vurgularken, gün geçtikçe daha fazla mekanik olan ve otomatlaşan endüstriyel alanların kültürel ve mesleki bilginin de artmasını gerektirdiğini söyler. Artık bir bütün halinde yapılan işlerde her parçada çalışan kişi önemli derecede sorumluluğa sahip olup bunlardan herhangi birisinin yapacağ yanlış tüm işi aksatacaktır. İşte bu nedenle tüm çalışanların çağın şartlarına göre kültürel seviyelerinin yükseltilmesi gereğini vurgular (Çağatay, 1959a).

Çağatay, eğitim ve öğretim ile ilgili yazı serisinin sonuncusunda hızla ilerleyen endüstrileşme ve üretim süreçlerinde tamamen otomatlaşmaya gidilmesi ile birlikte toplumun da ciddi bir değişime uğramaya başladığını belirtir. Bu değişim her şeyi kitlesel bir şekilde basitleştirmekte ve Çağatay'a göre bu durum avantajlarının yanında toplum hayatının gelişimi ve maddi ve manevi kültür değerleri açısından sakıncaları da yaratabilecektir (Çağatay, 1959b).

Dil Tarih Fakültesi Profesörü Dr. Hausmann'ın yapmış olduğu bir konuşmaya referansta bulunan Çağatay, 2. Dünya Savaşı sonrası Almanya'da yaşanan iktisadi kalkınma ve sonucu olan fiziki çalışma yerine 
artık makinelerin başında bekçilik haline gelen ve koyu renkli tulum işçiliğinden beyaz gömlekli nezaretçiliğe geçen insanın kültür ve bilgi seviyesine dikkat çeker. Ekonomik olarak bu kadar hızlı yaşanılan gelişmeler, zihni kültür seviyesi ile aynı hızda gitmez ve üretim ile tüketim arasındaki dengeyi bozabilir. Ancak bu bozulma yalnızca teknik ve ekonomik açıdan değil, toplumsal ve ahlaki açıdan da sorun çıarabilmekte ve bu da yalnızca ekonomik teknik ve teşkilatçlık sorunu değil; sosyal pedagojik bir sorun olmaktadır. Bu durum yalnızca okullarda verilen eğitim öğretimin yeterli olmaması ve dolayısıyla yetişkinlerin eğitimi konusunu ortaya çıkarmaktadır. Yine bir Alman mühendisinin yaptığı konuşmaya referansta bulunan Çağatay, Almanların 2. Dünya Savaşı sonrasında hızlıca kendilerini toplamasın "bilgi, görgü ve ihtisas" gibi değerlerini korumaları sayesinde gerçekleştirdiklerini belirtir, bu açıdan bilim, bilgi ve uzmanlığın kalkınma açısından önemine vurgu yapar (Çağatay, 1959b).

Çağatay, 2. Dünya Savaşından galibiyetle çıkan Amerika'nın kısa bir duraklama sonrası nasıl büyük bir güç haline geldiğini; Amerikalıların ilim, teknik ve eğitimi bütün işlerin temeli olarak almaları olarak açılar. Çağatay'a göre bu büyük gelişmenin sebebi bu ülkenin ilköğretimden başlayarak üniversite ve ihtisas eğitimine kadar bütün eğitim ve öğretim işlerinin koordine edilmesidir (Çağatay, 1959b).

Dünyanın her yerinde eğitim ve öğretim işlerinin çağdaş hayat şartlarına uygun olarak geliştirilmesinin ortak bir çözüm olduğunu belirten Çağatay, hayat şartlarının koşarcasına ilerlemekte ve zorlaşmakta olduğunu özellikle vurgular. İşte bu nedenle, her yaş ve seviyedeki insanın kültürünün geliştirilmesi, bu duruma ayak uydurabilmeleri için gereklidir. Çünkü dünyanın her yerinde hayatı kazanma imkânları da gittikçe daralmakta ve güçleşmektedir. Ama önemli olan nokta da insanları sadece bilgi bakımından geliştirmek değil, karakter ve irade bakımından da çok sağlam bir şekilde yetiştirmektir ve bu da tüm dünyanın ihtiyacıdır (Çağatay, 1959b).

Çağatay, toplumsal yaşamda karşımıza çıkan bu gelişmeler ve yenileşmelere uyum sağlayabilmek ve geride kalmamak için toplumsal ve kültürel yapının da çağdaş ihtiyaca yönelik olarak kalıp değiştirmesi gerekliliğine vurgu yapar. Ancak bu tarz değişikliklerin mutlaka birtakım huzursuzluklara yol açabileceği ve hatta bazı tepkilerle karşılaşılabileceğini de 
belirtir. Bir metafor kullanarak bu huzursuzluğa örnek veren Çağatay, eskimiş bir pabucun yerine yeni birisini giydiğimizde ayağımızda duyaca-

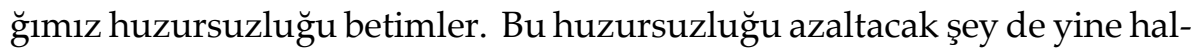
kın bu gerekliliğin önemini kavrayabilecek şekilde bir kültür seviyesinde olmasını, dolayısıyla eğitim ve öğretimin bu konudaki gerekliliğini göstermektedir (Çağatay, 1959b).

Demokrasi kavramına da vurgu yapan Çağatay, kitle demokrasisinin toplumların kaderini seçmenlere bağlaması olarak görür ve bu açıdan da oy verecek kişilerin belirli bir kültürel seviyeye ulaşmış olmasının önemini belirtir. Aksi takdirde kültürel seviyeye sahip olmayan bu kişiler demagojilere kanarak demokrasi ve hatta özgürlük rejimini dahi tehlikeye sokabileceklerdir. 19. Yüzyılda Batı ülkeleri zorunlu ilköğretime önem vermiş, yine okul yaşını tamamlayanların eğitimlerine de ciddi anlamda gayret göstermişlerdir. Çağatay bu açıdan Danimarka, İskandinavya, Hollanda, Belçika, İsviçre vd. ülkeleri örnek verir. Çağatay, UNESCO'nun yayınladığı bir rapora göre dünyada okuma yazma bilmeyen insan sayısının tüm nüfusun \%44'ü kadar olduğunu, bu durumun ülkelere göre farklılık gösterdiğini söyler. Bir ülkede bu durum \%95'e kadar çıkabilecekken, başka gelişmiş ülkelerde, İngiltere, Amerika Birleşik Devletleri, Fransa, en fazla $\% 4^{\prime}$ tür. Türkiye açısından durum $\% 65$ 'tir, seçmenlik hakkını kazanmış olan nüfusta yaş oranına göre bakıldığında yaş fazlalığı yönünde, kadın-erkek arasındaki gruplaşmaya bakıldığında da kadınlar arasında okuma-yazma bilmeyen sayısı çok artacaktır. Seçmenlerin doğru kararlar verebilmeleri kültür seviyelerinin artması ile dolayısıyla da okullarda çocuk ve gençlerin yetiştirilmesi ve seçmen yaşında olanların da görev ve sorumluluklarını bilecek seviyeye yükseltilmeleri gerekmektedir (Çağatay, 1959b).

Eğitim ve öğretimle doğrudan bağlantılı bir konu olan "gençlik" üzerine de düşüncelerini yazan Çağatay, Turan (1979) tarafından hazırlanan "Türkistan Bibliyografyası"nın ön sözünde hem Avrupa'da hem de memleketinde gençlerin araştırma ve inceleme eğilimine sahip olmalarına önem verdiğini belirtir. Yine gençlik hakkındaki düşüncelerini 1960 y1lında Türk Yurdu Dergisinde yayımladığı “Gençlik Kuşağı İ̧̧imai Önemi Büyük Olan Bir Zümredir" makalesiyle açılar. Her kuşağın kendine has toplumsal bir grup olduğuna vurgu yapan Çağatay, toplumsal hayatta yaşanan en büyük zorlukların; ihtiyarlar, iş ve vazife çağındaki olgunlar ve 
gençler olarak 3 tabakada ele aldığı kuşaklar arası ilişkilerin dengeli bir şekilde yürütülmesi gerekliliği olduğunu söyler. Genellikle genç ve ihtiyarlar arasında birisi geçmişe, diğeri de ileriye bağlı kaldıkları için sorunlar yaşanmakta, günü yaşayan orta kuşak da arada kalmaktadır. Çağatay, gençliği toplum açısından çok önemli bir zümre olarak görür. Gençliğin toplum içinde ne gibi roller ve görevler üstleneceğinin önemine değinir (Çağatay, 1960).

\section{Sonuç}

Türkistan kökenli Prof. Dr. Çağatay, farklı ülkelerde yaşamış ve hâkim olduğu yabancı diller sayesinde literatürdeki çok çeşitli yayınlara erişme olanağına sahip olmuş ve bu açıdan kendisini önemli derecede geliştirmiş, Türkiye'de alana önemli katkılar sağlamış sosyologlardandır. Çağatay, sosyolojiden felsefeye, hukuktan iktisat ve tarihe, ekonomi ve zirai alanlara kadar çok yönlü çalışmalarda bulunmuştur. Daha çok ekonomi ve ziraat konusundaki çalışmaları ile tanınsa da kadın konusunu ilk ele alan, medyanın gücüne vurgu yapan, sinema ve edebiyat hakkında görüşlerini de belirten Çağatay, gençlik, aile ve eğitim-öğretim konularında da düşüncelerini ortaya koymuştur.

Tek bir alanda çalışmayan ve bilimsel açıdan çok yönlü olan Çağatay, eğitim ve öğretim konusundaki görüşlerini açıklarken günümüz şartlarının değişimine vurgu yapmıştır. Bu açıdan eğitim ve öğretimin de çağın gerektirdiği şekilde yenilenmesi ve değiştirilmesini belirtmiştir. Ülkeler bağlamında örnekler veren Çağatay, pek çok ülkenin eğitim sistemlerinde yaptıkları reformlar sayesinde güç kazandıklarını ve çağın gereklerine uygun gelişmeleri eğitim sistemlerine yansıttıkları için başarı elde ettiklerini belirtmiştir. Günümüzden 59 yıl önce yazdığı eserleriyle, halen çok önemli bir olgu olan "yenileşme" ye önem verdiği özellikle göze çarpmaktadır. Hem geleneksel sosyoloji hem de dönemi açısından yenilik sayılan konular üzerinde düşüncelerini belirten Çağatay, toplumdaki değişmeler karşısında pedagojinin yeterli olmadığı ve bu nedenle sosyoloji ve hatta felsefenin eğitim ile iç içe olması gerektiğine vurgu yapmıştır. Çağatay'ın yaklaşık 60 yıl önce kaleme aldığı düşüncelerinin günümüzdeki gelişmeler ile oldukça benzer özellikler gösterdiği görülmektedir. Özellikle deği- 
şen toplumlarda okulların artık tek bilgi edindirme yerleri olmadığı vurgusunu yapması ve okullarda uygulanan yöntem ve tekniklerin çağa uygun olarak yenilenmesini vurgulaması bu açıdan önemlidir. Ancak Çağatay, ilerleme ve gelişmeye önem verilmesini vurgularken taklitçilikten kaçınmak gerektiğine özellikle değinmiş ve her toplumun kendi özelliğine uygun bir gelişim ve değişim yolu izlemesi gerektiğini belirtmiştir. Yine Çağatay, dünyanın sadece bilgi ile eğitilen değil, aynı zamanda karakter ve irade bakımından da yetiştirilen insanlara ihtiyacı olduğunu vurgulayarak günümüzdeki değerler eğitimine de değinmektedir. Yazılarında yetişkin eğitimine de vurgu yapan Çağatay, özellikle demokrasi ve özgürlük rejiminin korunması açısından seçmen yetişkinlerin de farklı demagojilerden etkilenmeyecek bir kültürel seviyeye ulaşmalarını vurgular. Pek çok alanda çok yönlü çalışmalar yapan Çağatay'ın eğitim ve öğretim konusunda da aynı şekilde disiplinler arası bir bakış açısına sahip olduğu görülmektedir. 


\section{EXTENDED ABSTRACT}

\section{Views of Tahir Çağatay on Education and Training}

\section{A. Selcen Arslangilay \\ Gazi University}

Tahir Çağatay, a Turkistani Turkish Professor of Sociology in Faculty of Language, History and Geography in Ankara University , lived in various countries such as Uzbekistan, Russia, Germany and Turkey. By the virtue of the foreign languages he knew (Russian and German), he had the chance to access the various publications in the literature. Therefore he could improve himself academically and contributed to the sociology field in Turkey considerably. Çağatay has made various multi-directional studies on sociology to philosophy, law to economy and history and also agricultural field. Although he is mostly known with his academic studies in economy and agriculture, he is the first to deal with woman issue. In addition, he had made emphasis to the power and effect of media and also stated his views about cinema and literature. Çağatay had also explained his opinions on the youth, family and also education and training.

As a sociologist who had worked on various fields and multi-dimensional in terms of scientific research, Çağatay had explained his views about education and training in the articles published in Türk Yurdu Journal as three series in 1959 with the title "Innovation is a Social Necessity in Education and Training". In this study, Çağatay's opinions about education and training has been tried to be presented according to these articles. The fact that Çağatay had been focusing on the changes lived in the conditions of the time while presenting his views on education and training draws our attention. Therefore he stated that education and training should be modernized and improved according to the needs of the time. In his three series articles on education and training, Çağatay had given examples within the context of some countries; such as America and Germany after the Second World War or again the Netherlands and the other countries who lost their colonies and also developing countries such as India or China and other Asian and African countries who were stuggling to get 
rid of their being a colonial country and trying to develop and improve themselves. In this respect Çağatay states that all these countries have gained power as they made some reforms in their education systems and have reflected the required developments of the time to their educational systems. Although he wrote these three series articles 59 years ago, what draws our attention is that he had given importance to "innovation" which is a very important phenomenon of our time. Çağatay had worked on subjects in terms of both traditional sociology and which could be seen as innovative according to his time.

According to Çağatay, pedagogy is no more sufficient in a time which has many changes, so that sociology as well as philosophy should be handled with education and training. In his opinions which he had mentioned nearly 60 years ago, we see a correspondence with the developments seen in today's time. Especially in terms of his statement that with the rapidly changing societies, schools are no more the only places for acquisition of knowledge. And the fact that the methods and techniques to be used in the schools should be updated according to the needs of the time is important in this respect. But it is a very important aspect that Çağatay emphasizes keeping away from imitation while attaching importance on development and improvement. In this respect he states that every society should follow a development route proper to their own characteristics. Again, what is mostly emphasized by Çağatay is that, only the attainment of knowledge would never be sufficient as the world needs individuals who are both literate and culturally competent as well as developed in terms of character and self control. Here it could be said that he had given importance to values education which is still an important aspect of education systems.

Çağatay refers to compulsory education such as primary education as well as vocational education and also adult education. In terms of adult education, he states that adults as parents should be culturally competent to raise their children in cooperation with the school and help their children in the world outside the school. In the context of securing democracy and freedom regime, Çağatay again puts emphasis on adult education. Because adults as voters should be such culturally and educationally competent so that they would not be effected by any demagogies which would harm the democracy. It is clearly seen that as a sociologist who had 
worked in many fields, Çağatay had a very interdisciplinary and innovative point of view also in his opinions on education and training.

\section{Kaynakça / References}

Açık, F. (2009). Nevai şahsında Sovyet bakış açısının Yaş Türkistan Dergisi'nde eleştirisi. A.Ü. Türkiyat Araştırmalarn Enstitüsü Dergisi, 39, 909-918.

Ayan, D. (2008). Tahir Çağatay. M. Ç. Özdemir (Ed.), Türkiye'de sosyoloji (isimler-eserler) I, (ss. 683-702). Ankara: Phoenix Yayınevi.

Ayan, D. (1996). Prof. Dr. Tahir Çağatay (27.3.1902-27.7.1984). Türkiye Cumhuriyeti Devletinin kuruluş ve gelişmesine hizmeti geçen Türk Dünyası aydınları sempozyumu bildirileri (23-26 Mayıs 1996). Kayseri: Erciyes Üniversitesi Türk Araştırmaları Merkezi Yayınları.

Ayas, M. R. (1994). Bir gerçeklik bilimi olarak sosyoloji ve Tahir Çağatay. Ankara Üniversitesi İlahiyat Fakültesi Dergisi, 33, 11-40.

Bayraktar, R. (2013). Türkistanlı aydınlarımızın siyasi ve yayın mücadelesi: Mustafa Çokayoğlu ve etrafındakiler. Atatürk Üniversitesi İlahiyat Fakültesi Dergisi, 39, 307-336.

Çağatay, S. İ. (1984). 'Prof. Dr. Tahir Çağatay (27.3.1902-27.7.1984). Emel, 141-145, Mart-Aralık, 86.

Çağatay, T. (1959). Eğitim ve Öğretimde Yenilik İçtimai Zarurettir I. Türk Yurdu, 275, 15-16.

Çağatay, T. (1959a). Eğitim ve Öğretimde Yenilik İçtimai Zarurettir II. Türk Yurdu, 276, 31-32.

Çağatay, T. (1959b). Eğitim ve Öğretimde Yenilik İçtimai Zarurettir III. Türk Yurdu, 277, 22-24.

Çağatay, T. (1960). Gençlik Kuşağı İçtimai Önemi Büyük Olan Bir Zümredir. Türk Yurdu, 290, 9-10.

Çeçen, A. (1977). Siyasal rejimlerin sosyal yapıları. Ankara Üniversitesi Hukuk Fakültesi Dergisi, 34(1).

Çelebi, N. (2008). Sosyoloji sosyoloğun yaptığı ise. Türkiyat Araştırmaları, Prof. Dr.M.Cihat Özönder'in Anısina 1.cilt, 8, 69-80.

Erbaş, H. (2015). Türkiye' de bedeller ödemiş bir sosyolojik düşünce ustası: Sosyolog Behice Boran. Mülkiye Dergisi, 39(3), 5-57. 
Erdoğan, İ. (2009). Türkiye' de iletişim araştırmalarının geleceği. K. Alemdar (Der.) Türkiye'de Kitle İletişimi: Dün-Bugün-Yarm (2009).(ss.130). Ankara: Gazeteciler Cemiyeti yayını.

Güçlü, M. (2013). Cumhuriyetin öncü eğitimcilerinden Dr. Halil Fikret Kanad'ın süreli yayınlarda yayımlanan yazılarının değerlendirilmesi, Turkish Studies, 8(11), 113-129.

Güçlü, M. (2015). Türkiye'de 1950 ve 1980 yılları arasında süreli yayınlara yansıyan mesleki ve teknik öğretimle ilgili konuların değerlendirilmesi: Mesleki ve teknik öğretim dergisi örneği. Turkish Studies, 10(14), 363-386.

Kasapoğlu, A. (1999). 60 Yillık Gelenek: DTCF'de Uygulamalı Sosyoloji. Ankara: Ümit Ofset Matbaacilık ve Yayıncilı.

Ono, R. (2013). Muhacerattaki bir Özbek Türkü'nün mektuplarına göre Türk dünyası-Abdülvahap Oktay ve mektupları. Ankara Üniversitesi Dil ve Tarih-Coğrafya Fakültesi Dergisi, 53(2), 563-584.

Sarıtaş, M. (1985). İdeoloji, sosyoloji ve metodoloji: Tahir Çağatay üzerine bir değerlendirme. Türkiye Kültür ve Sanat Yıllığı. (ss. 526-527) Ankara.

Torun, H. (2002). Tahir Çă̆atay'ın hayatı ve faaliyetleri. Yayımlanmamış Yüksek Lisans Tezi. İstanbul: İstanbul Üniversitesi, Sosyal Bilimler Enstitüsü, Tarih Anabilim Dalı.

Turan, Ş. (1979). Türkistan bibliyografyası. Ankara: Ayyıldız Matbaası.

Yaman, E. (1999). Osmanlı'dan günümüze Türkistan-Türkiye kültür ilişkilerine genel bir bakış. İslami Araştırmalar Dergisi, 12(2), 191-201.

\section{Kaynakça Bilgisi / Citation Information}

Arslangilay, A. S. (2018). Tahir Çağatay'ın eğitim ve öğretime dair görüşleri. OPUS - Uluslararası Toplum Araştırmaları Dergisi, 8(14), 537554. DOI: $10.26466 /$ opus.405531 